\title{
EKSTRAK TEMU PUTIH (Curcuma zedoaria Rosc.) DAN EKSTRAK DAUN SIRIH MERAH (Piper crocatum) BERPOTENSI MENURUNKAN KUALITAS SPERMATOZOA MENCIT (Mus musculus L.)
}

\author{
Sukarjati $^{1)}$ dan Yoga Bagas Pratama ${ }^{2)}$ \\ ${ }^{1.2}$ Prodi Biologi F.MIPA Universitas PGRI Adi Buana Surabaya \\ Email: sukarjati@ymail.com
}

\begin{abstract}
Abstrak
Temulawak putih (Curcuma zedoaria Rosc) dan daun sirih merah (Piper crocatum) merupakan tanaman yang diduga memiliki aktivitas sebagai antifertilitas dalam hal mempengaruhi kualitas sperma. Penelitian ini bertujuan untuk mengetahui pengaruh tanaman temulawak putih (Curcuma zedoaria Rosc) dan daun sirih merah (Piper crocatum) terhadap kualitas sperma serta mengetahui dosis dari ekstrak etanol temulawak putih (Curcuma zedoaria Rosc) dan daun sirih merah (Piper crocatum) yang dapat mempengaruhi kualitas sperma pada hewan coba mencit (Mus musculus L.). Mencit dikelompokkan menjadi 4 kelompok perlakuan yaitu kontrol, $50 \mathrm{mg} / \mathrm{mg} \mathrm{BB,} 100 \mathrm{mg} / \mathrm{mg} \mathrm{BB}$, $150 \mathrm{mg} / \mathrm{mg}$ BB. Diberi perlakuan selama 35 hari dengan tiga kali ulangan. Mencit dibedah dan diambil semen pada bagian vas deferens lalu diamati pergerakan sperma dibawah mikroskop. Hasil menunjukkan bahwa ekstrak etanol temulawak putih (Curcuma zedoaria Rosc) dan daun sirih merah (Piper crocatum) memiliki aktivitas mempengaruhi kualitas sperma pada dosis diatas $50 \mathrm{~kg} / \mathrm{mg}$ BB yang berdasarkan data analisis statistik memperlihatkan perbedaan yang signifikansi dengan kontrol negatif.
\end{abstract}

Kata Kunci : Temu Putih (Curcuma zedoaria Rosc.), Sirih Merah (Piper crocatum), spermatozoa, Mencit Jantan (Mus musculus L.)

\begin{abstract}
White ginger (Curcuma zedoaria Rosc) and red betel leaf (Piper crocatum) are plants that are thought to have antifertility activity in terms of affecting sperm quality. This study aims to determine the effect of white ginger (Curcuma zedoaria Rosc) and red betel leaves (Piper crocatum) on sperm quality and to determine the dose of ethanol extract of white temulawak (Curcuma zedoaria Rosc) and red betel leaf (Piper crocatum) which can affect the quality sperm in experimental animals mice (Mus musculus L.). Mice are grouped into 4 treatment groups namely control, $50 \mathrm{mg} / \mathrm{mg} \mathrm{BB}, 100 \mathrm{mg} / \mathrm{mg} \mathrm{BW}, 150 \mathrm{mg} / \mathrm{mg}$ BB. It was treated for 35 days with three replications. Mice are dissected and semen is taken in the vas deferens and sperm is observed under a microscope. The results showed that ethanol extract of white temulawak (Curcuma zedoaria Rosc) and red betel leaf (Piper crocatum) had an effect on sperm quality at doses above $50 \mathrm{~kg} / \mathrm{mg} B B$ which based on statistical analysis data showed significant differences with negative controls.
\end{abstract}

Keywords: White genger (Curcuma zedoaria Rosc.), Red Betel (Piper crocatum), spermatozoa, Male Mice (Mus musculus L.)

\section{PENDAHULUAN}

Indonesia merupakan negara dengan jumlah penduduk terbanyak ke-empat di dunia yaitu 255.182.144 jiwa ditahun 2010 dengan laju pertumbuhan penduduk $1.3 \%$ dengan jumlah terbanyak 58 persen di Pulau
Jawa. Indonesia juga merupakan negara berkembang dengan banyak masalah salah satunya adalah bidang kependudukan yang terus meningkat pertumbuhan penduduknya. Pertumbuhan penduduk yang semakin tinggi 
akan mempersulit usaha peningkatan dan pemerataan kesejateraan hidup, semakin tinggi pertumbuhan penduduk semakin besar usaha yang dilakukan oleh pemerintah untuk mensejaterakan rakyat (BPS, 2011).

Pemerintah berupaya menekan laju pertumbuhan penduduk dengan keluarga berencana (KB), Pencapaian tujuan dan sasaran dari kebijakan kependudukan tersebut telah dirumuskan berbagai kebijaksanaan, antara lain meliputi peningkatan kualitas penduduk, pengendalian pertumbuhan dan kualitas penduduk dalam rangka menekan dan mengendalikan pertambahan jumlah penduduk (BPS, 2011)

Laki-laki merupakan fokus baru dalam program KB yang selama ini belum banyak diperhatikan, sehingga masalah ini yang menjadi landasan mengapa perkembangan teknologi kontrasepsi lebih mengarah pada laki-laki (Wilopo,2006). Metode kontrasepsi laki-laki sampai saat ini yang dianggap mantap adalah kondom dan vasektomi (Moeloek, 2002 dan Sumaryati, 2004), tetapi penggunaan kondom sebagai alat kontrasepsi menimbulkan keluhan psikologik, sedangkan vasektomi walaupun merupakan kontrasepsi yang diandalkan sering menimbulkan efeksamping yang permanen yaitu bisa terjadi kegagalan rekanalisasi. Alternatif lain dalam metode kontrasepsi laki-laki yaitu penggunaan hormon tetapi belum memuaskan dan perlu dilakukan penelitian tentang alat kontrapsi alternatif (Moeloek, 2002).

Penelitian penggunaan bahan alam sebagai bahan pengobatan telah banyak dilakukan. Penelitian menggunakan rimpang temu putih (Curcuma zedoaria (Berg.) Roscoe.) diketahui mengandung 1-2,5\% minyak dengan komposisi utama adalah sesquiterpen. Minyak menguap mengandung lebih dari 20 komponen seperti curzerenone (zedoarin) yang merupakan komponen terbesar, flavonoid, sulfur, gum, resin, tepung, sedikit lemak (Murwati, R, E. Meiyanto. 2004) dan senyawa yang berkhasiat obat, yaitu kurkuminoid yang terdiri dari kurkumin, desmetoksikurkumin dan bisdesmetoksi kurkumin (Handajani,
2003). Menurut (Murwati, R, E. Meiyanto. 2004) rimpang temu putih mengandung saponin, flavonoid, dan polifenol. Senyawa lain juga ditemukan pada rimpang temu putih seperti tanin, glikosida, triterpenoid dan alkaloid (Haryati. 2003). Antifertilitas dari tumbuhan Sirih (Piper crocatum) juga pernah dilakukan, yaitu dengan ekstrak air daun Sirih. Menurut (Ratnasooria dan Pemakumara, 1997) ekstrak air daun Sirih (Piper crocatum). dapat menghambat kesuburan tikus putih jantan galur secara tidak permanen.

\section{METODE PENELITIAN}

Penelitian ini merupakan penelitian eksperimental menggunakan Rancangan Acak Lengkap (RAL). Penelitian ini dilakukan untuk mencari pengaruh perlakuan tertentu terhadap yang lain dalam kondisi yang terkendalikan. Rancangan acak lengkap ini merupakan rancangan yang paling sederhana karena bahan percobaan yang digunakan harus homogen. Kehomogenan yang dimaksud adalah hewan percobaan, kandang, umur, bobot, dan factor lainnya.

\subsection{Populasi dan Sampel}

Populasi pada penelitian ini yaitu mencit yang sehat dan tidak bercacat, berumur 3 bulan, dengan bobot mencit 25-30 gram yang diperoleh dari laboratorium PUSVETMA Surabaya. Sampel pada penelitian ini yaitu preparat histologi hati dan ginjal mencit yang berasal dari beberapa kelompok perlakuan yang telah ditentukan. Jumlah mencit yang digunakan pada penelitian ini sebanyak 36 mencit yang terdiri dari 12 perlakuan dengan 3 kali pengulangan.

\subsection{Persiapan hewan uji}

Persiapan hewan uji ini yaitu dengan menimbang bobot badan awal mencit, pemberian ransum pakan dan minum yang disediakan dalam kandang dengan penutup kawat kasa diatas yang diberikan botol dan minuman. Kandang berjumlah 12 dengan masing-masing perlakuan berjumlah 3 ekor mencit. Mencit di adaptasikan pada suhu laboratorium selama 7 hari agar dapat 
beradaptasi dengan kondisi lingkungan yang baru.

\subsection{Perlakuan Hewan Uji}

Ekstrak diberikan secara oral menggunakan sonde (alat pencekok) dengan volume $0,5 \mathrm{ml}$ pada masing-masing ekstrak. Pemberian ekstrak pada masing-masing perlakuan dilakukan pada sore hari selama 35 hari dengan dosis yang telah dihitung sesuai dengan $\mathrm{mg} / \mathrm{kgBB}$ mencit. Pada hari ke-36 dilakukan terminasi pada mencit dengan cara dibius dan diambil organ hati dan ginjal untuk dibuat preparat histologi hati dan histologi ginjal.

\subsection{Pembuatan Ekstrak}

Temu putih dan daun sirih merah dicuci bersih, kemudian untuk temu putih di iris tipis-tipis dan untuk daun sirih merah biarkan tetap berupa lembaran daun kemudian diletakkan dibawah sinar matahari untuk dikeringkan, jika sinar matahari belum cukup untuk membuat temu putih dan daun sirih merah kering maka diangin-anginkan. Ketika temu putih dan daun sirih merah telah kering maka dihaluskan menggunakan blender pada masing-masing bahan tersebut. Setelah dihaluskan kemudian serbuk simplisia masing-masing sebanyak 100 gr dimaserasi dengan alkohol $80 \%$ sebanyak 1000 ml. Kemudian ekstrak tersebut dibungkus menggunakan kain putih dan diikat. Masukkan kedalam toples dan direndam dengan pelarut alkohol 80\% selama 3 hari pada suhu kamar. Kemudian air ekstrak dipisahkan dari ampasnya hingga diperoleh maserat jernih. Semua maserat didestilasi dengan bantuan alat rotary evaporator selama 8 jam dengan suhu maksimum $70^{\circ} \mathrm{C}$.

\subsection{Pemberian Perlakuan Ekstrak}

Ekstrak temu putih dan daun sirih merah dilarutkan dalam aquadest. Ekstrak diberikan secara oral menggunakan sonde dengan volume $0,5 \mathrm{ml}$ pada masing-masing ekstrak selama 35 hari.

\subsection{Pembuatan Dosis Ekstrak}

Pada penelitian ini dilakukan pembuatan dosis ekstrak dengan perhitungan yang digunakan menurut Ervina Layuk (2016) adalah sebagai berikut :

Dosis $($ per $1 \mathrm{ml})=\underline{\text { Dosis } \mathrm{x} \text { bobot mencit }}$

Konsentrasi

Diketahui : berat badan mencit $=26 \mathrm{gr}=$ $0,026 \mathrm{~kg}$

a. Dosis $25 \mathrm{mg} / \mathrm{KgBB}$

$25 \mathrm{mg} / \mathrm{KgBB} \quad \mathrm{x} \quad 0,026 \mathrm{~kg}=0,65$ $\mathrm{mg} / \mathrm{KgBB}$

$0,65 \mathrm{mg} / \mathrm{KgBB} \quad \mathrm{x} \quad 1,5 \mathrm{ml}=0,975$ $\mathrm{mg} / \mathrm{KgBB}$ ekstrak dilarutkan dalam 0,5 $\mathrm{ml}$ aquadest.

b. Dosis $50 \mathrm{mg} / \mathrm{KgBB}$

$50 \mathrm{mg} / \mathrm{KgBB} \times 0,026 \mathrm{~kg}=1,3 \mathrm{mg} / \mathrm{KgBB}$

$1,3 \mathrm{mg} / \mathrm{KgBB}$ x 3 ekor $=3,9 \mathrm{mg} / \mathrm{KgBB}$

ekstrak dilarutkan dalam $0,5 \mathrm{ml}$ aquadest.

c. Dosis $75 \mathrm{mg} / \mathrm{KgBB}$

$75 \mathrm{mg} / \mathrm{KgBB} \quad \mathrm{x} \quad 0,026 \mathrm{~kg}=1,95$ $\mathrm{mg} / \mathrm{KgBB}$

$1,95 \mathrm{mg} / \mathrm{KgBB} \quad \mathrm{x} \quad 1,5 \mathrm{ml}=2,925$ $\mathrm{mg} / \mathrm{KgBB}$ ekstrak dilarutkan dalam 0,5 $\mathrm{ml}$ aquadest.

d. Dosis $100 \mathrm{mg} / \mathrm{KgBB}$

$100 \mathrm{mg} / \mathrm{KgBB} \quad \mathrm{x} \quad 0,026 \quad \mathrm{~kg}=2.6$ $\mathrm{mg} / \mathrm{KgBB}$

$2,6 \mathrm{mg} / \mathrm{KgBB}$ × 3 ekor $=7,8 \mathrm{mg} / \mathrm{KgBB}$ ekstrak dilarutkan dalam $0,5 \mathrm{ml}$ aquadest.

e. Dosis $150 \mathrm{mg} / \mathrm{KgBB}$

$150 \mathrm{mg} / \mathrm{KgBB} \quad \mathrm{x} \quad 0,026 \quad \mathrm{~kg}=3,9$ $\mathrm{mg} / \mathrm{KgBB}$

$3,9 \mathrm{mg} / \mathrm{KgBB}$ × 3 ekor $=11,7 \mathrm{mg} / \mathrm{KgBB}$ ekstrak dilarutkan dalam $0,5 \mathrm{ml}$ aquadest.

\subsection{Penghitugan morfologi spermatozoa mencit}

Morfologi spermatozoa yang normal dan abnormal dilihat pada bagian kepala dan ekor yang berbeda dari normal. Misalnya kepala ganda, kepala berukuran kecil, atau terlalu besar, tanpa kepala, ekor gamda, ekor tidak lurus, mengkerut, ekor patah, atau tanpa ekor. Pengamatan morfologi spermatozoa ditentukan dengan cara membuat sediaan apus dari satu tetes suspensi pada objek glass spermatozoa dan difikasi di udara sampai kering, kemudian diwarnai dengan safranin, 
direndam dalam larutan alkohol 70\% selama 5 menit, kemudian dicelup cepat dengan buffer fosfat sebanyak 3 kali selanjutnya diwarnai dengan cristal voilet selama 10 menit, dicuci air mengalir dan dikeringkan. Selanjutnya dihitung spermatozoa normal dan abnormal pada 100 spermatozoa untuk setiap ulangan. Perhitungan dilakukan di bawah mikroskop dengan perbesaran 400 kali.

\subsection{Penghitugan motilitas spermatozoa mencit}

Pengambilan spermatozoa pada epididimis dengan metode cacah dan menggunakan pengenceran dengan garam fisiologi sebesar $1 \mathrm{ml}$. Untuk pengamatan motilitas spermatozoa dapat dilakukan dengan mengamati spermatozoa yang telah ditetesi ke bilik hitung dengan perbesaran 400 kali. Motilitas sperma ditentukan dari 100 spermatozoa dalam satu lapang pandang. Persentase motilitas spermatozoa dihitung dengan cara membagi total jumlah kategori motilitas spermatozoa $(a+b)$ dengan jumlah total spermatozoa $(\mathrm{a}+\mathrm{b}+\mathrm{c}+\mathrm{d})$ dikalikan dengan $100 \%$. Motilitas spermatozoa dinilai berdasarkan persen spermatozoa dengan motilitas baik, yaitu spermatozoa yang dikategorikan:
a. Jika spermatozoa bergerak cepat lurus kedepan.
b. Jika spermatozoa bergerak lambat.

\subsection{Penghitugan viabilitas spermatozoa mencit}

Larutan spermatozoa diambil satu tetes pada objek glass. Sampel kemudian ditetesi dengan larutan eosin-Ysatu tetes dicampur, ditutup dengan kaca penutup, pengamatan dilakukan dibawah mikroskop dengan perbesaran 400 kali. Persentase jumlah spermatozoa hidup dapat diketahui dengan menghitung jumlah spermatozoa hidup dari 100 spermatozoa untuk setiap ulangan. Spermatozoa yang hidup tidak harus bergerak tapi memiliki kepala berwarna hijau sedangkan yang mati berwarna merah (WHO, 1998).

\subsection{Penghitugan konsentrasi spermatozoa mencit}

Larutan spermatozoa diambil sebanyak $10 \mu \mathrm{l}$ dengan menggunakan pipet mikro. Setelah itu dilakukan pengecekan sebanyak 10 kali dengan menambahkan larutan goerge sebanyak $90 \mu \mathrm{l}$ dalam tabung mikro. Larutan spermatozoa tersebut lalu dikocok kemudian diteteskan ke dalam kamar hitung hemasitometer improved neubauer yang telah diberi kaca penutup. Perhitungan dilakukan di bawah mikroskop dengan perbesaran 400 kali. Spermatozoa yang berada pada 25 kotak kecil yang digunakan untuk penghitungan sel darah merah dijumlahkan.

\subsection{Analisi Data}

Data hasil penelitian diuji dengan ANOVA . Ada pengaruh ekstrak temu lawak putih dan ekstrak daun sirih merah serta kombinasi kedua ekstrak, terhadap kualitas sperma maka dilanjutkan dengan uji LSD (Leas Significant Different) untuk mengetahui perbedaan pada setiap perlakuan. Analisis ini dilakukan dengan menggunakan program SPSS.

\section{HASIL DAN PEMBAHASAN \\ 3.1. Hasil \\ Motilitas spermatozoa}

Hasil penelitian dan analisa pengaruh pemberian sirih merah (Piper crocatum) ekstrak temu putih (Curcuma zedoaria Rosc) serta kedua kombinasi terhadap penurunan motilitas spermatozoa di sajikan dalam Grafik. 1. Rata-rata motilitas spermatozoa disajikan dalam diagram batang sebagai berikut:

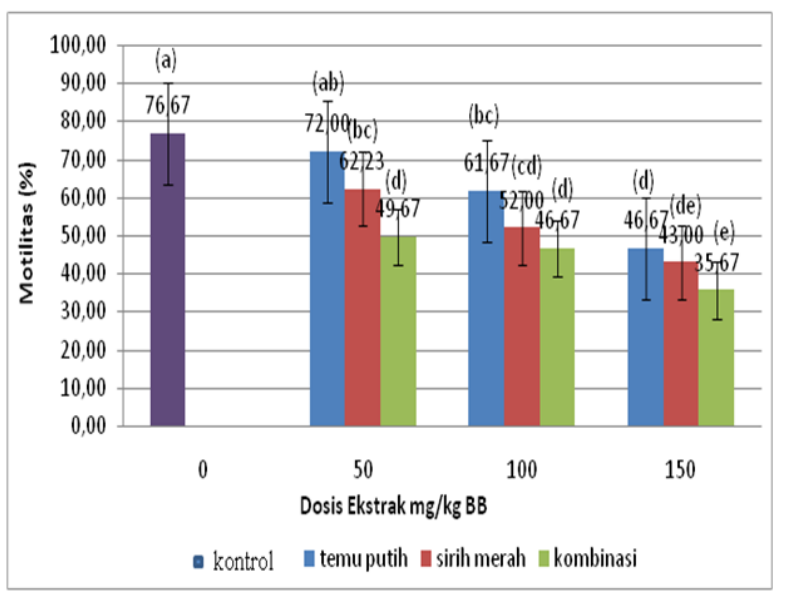


Berdasarkan diagram diatas menunjukkan bahwa rata-rata motilitas pada kelompok perlakuan ekstrak daun sirih merah dan ekstrak temu putih serta kombinasi kedua ekstrak lebih rendah dibanding pada kelompok kontrol.

Dari hasil analisa data menggunakan one way Anova di dapat hasil bahwa ada pengaruh pemberian ekstrak pada berbagai dosis terhadap motilitas spermatozoa mencit $(\mathrm{P}=0,000)$ disajikan dalam lampiran 1 . Berdasarkan hasil SPSS Uji LSD menunjukkan bahwa motilitas pada perlakuan kontrol berbeda signifikan terhadap semua perlakuan ekstrak kecuali ekstrak temu putih $50 \mathrm{mg} / \mathrm{kg}$ BB. Motilitas pada perlakuan temu putih $50 \mathrm{mg} / \mathrm{kg}$ BB berbeda signifikan terhadap semua perlakuan ekstrak. Motilitas pada perlakuan temu putih $100 \mathrm{mg} / \mathrm{kg} \mathrm{BB}$ berbeda signifikan terhadap semua perlakuan ekstrak kecuali ekstrak sirih merah $50 \mathrm{mg} / \mathrm{kg}$ BB.

Motilitas pada perlakuan temu putih $150 \mathrm{mg} / \mathrm{kg}$ BB tidak berbeda signifikan terhadap semua perlakuan ekstrak kecuali ekstrak sirih merah $50 \mathrm{mg} / \mathrm{kg}$ BB dan kombinasi ekstrak 75:75 mg/kg BB. Motilitas pada perlakuan sirih merah 50 $\mathrm{mg} / \mathrm{kg}$ BB berbeda signifikan terhadap semua perlakuan ekstrak. Motilitas pada perlakuan sirih merah $100 \mathrm{mg} / \mathrm{kg}$ BB tidak berbeda signifikan terhadap semua perlakuan ekstrak kecuali kombinasi ekstra $75: 75 \mathrm{mg} / \mathrm{kg}$ BB. Motilitas pada perlakuan sirih merah 150 $\mathrm{mg} / \mathrm{kg}$ BB tidak berbeda signifikan terhadap semua perlakuan ekstrak. Motilitas pada kombinasi ekstrak 25:25 mg/kg BB tidak berbeda signifikan terhadap kombinasi ekstrak $50: 50 \mathrm{mg} / \mathrm{kg} \mathrm{BB}$, tetapi berbeda signifikan terhadap kombinasi ekstrak 75:75 $\mathrm{mg} / \mathrm{kg}$ BB. motilitas pada perlakuan kombinasi ekstrak 50:50 berbeda signifikan terhadap kombinasi ekstrak 75:75 mg/kg BB.

\section{Viabilitas spermatozoa}

Hasil penelitian dan analisa pengaruh pemberian sirih merah (Piper crocatum) ekstrak temu putih (Curcuma zedoaria Rosc) serta kedua kombinasi terhadap penurunan viabilitas spermatozoa di sajikan dalam
Grafik 2. Rata-rata motilitas spermatozoa disajikan dalam diagram batang sebagai berikut:

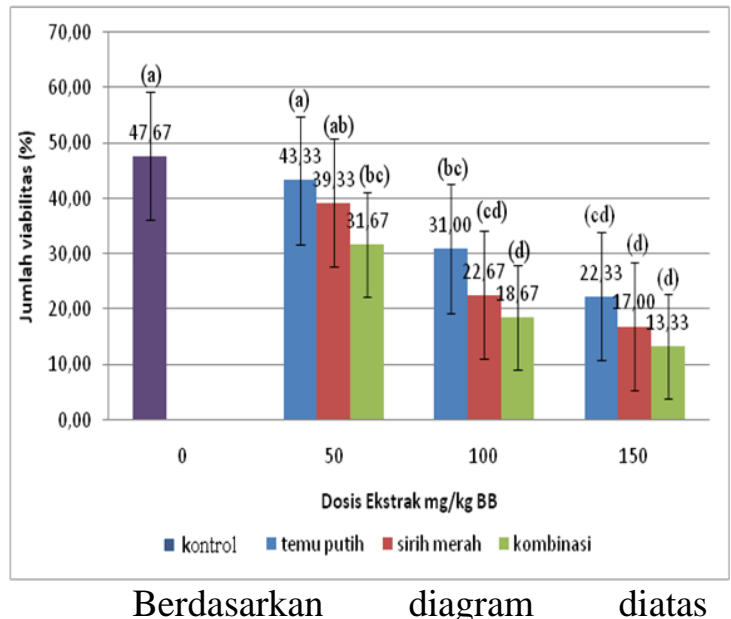

menunjukkan bahwa rata-rata viabilitas pada kelompok perlakuan ekstrak daun sirih merah dan ekstrak temu putih serta kombinasi kedua ekstrak lebih rendah dibanding pada kelompok kontrol.

Dari hasil analisa data menggunakan one way Anova di dapat hasil bahwa ada pengaruh pemberian ekstrak pada berbagai dosis terhadap penurunan viabilitas spermatozoa mencit ( $\mathrm{P}=0,000)$ disajikan dalam lampiran 2. Berdasarkan hasil SPSS Uji LSD menunjukkan bahwa viabilitas pada perlakuan kontrol berbeda signifikan terhadap semua perlakuan ekstrak kecuali ekstrak temu putih $50 \mathrm{mg} / \mathrm{kg}$ BB dan ekstrak sirih merah $50 \mathrm{mg} / \mathrm{kg}$ BB. Viabilitas pada perlakuan ekstrak temu putih $50 \mathrm{mg} / \mathrm{kg} \mathrm{BB}$ berbeda signifikan terhadap semua perlakuan ekstrak kecuali sirih merah $50 \mathrm{mg} / \mathrm{kg}$ BB. Viabilitas pada perlakuan ekstrak temu putih $100 \mathrm{mg} / \mathrm{kg}$ BB berbeda signifikan terhadap semua perlakuan ekstrak kecuali ekstrak sirih merah $150 \mathrm{mg} / \mathrm{kg}$ BB, kombinasi ekstrak $50: 50 \mathrm{mg} / \mathrm{kg}$ BB dan kombinasi estrak 75:75 $\mathrm{mg} / \mathrm{kg} \mathrm{BB}$.

Viabilitas pada perlakuan temu putih $150 \mathrm{mg} / \mathrm{kg}$ BB tidak berbeda signifikan terhadap semua perlakuan ekstrak kecuali ekstrak sirih merah $50 \mathrm{mg} / \mathrm{kg}$ BB. viabilitas pada perlakuan sirih merah $50 \mathrm{mg} / \mathrm{kg}$ BB berbeda signifikan terhadap semua perlakuan ekstrak kecuali kombinasi ekstrak 25:25 $\mathrm{mg} / \mathrm{kg}$ BB. Viabilitas pada perlakuan sirih 
merah $100 \mathrm{mg} / \mathrm{kg} \quad \mathrm{BB}$ tidak berbeda signifikan terhadap semua perlakuan ekstrak. Viabilitas pada perlakuan sirih merah 150 $\mathrm{mg} / \mathrm{kg}$ BB tidak berbeda signifikan terhadap semua perlakuan ekstrak kecuali kombinasi ekstrak 25:25 mg/kg BB. Viabilitas pada perlakuan kombinasi ekstrak 25:25 mg.kg BB berbeda signifikan terhadap semua perlakuan ekstrak. Viabilitas pada perlakuan kombinasi ekstrak $50: 50 \mathrm{mg} / \mathrm{kg}$ BB tidak berbeda signifikan terhadap kombinasi 50:50 $\mathrm{mg} / \mathrm{kg} \mathrm{BB}$.

\section{Morfologi spermatozoa}

Hasil penelitian dan analisa pengaruh pemberian sirih merah (Piper crocatum) ekstrak temu putih (Curcuma zedoaria Rosc) serta kedua kombinasi terhadap penurunan morfologi spermatozoa di sajikan dalam lampiran 3. Rata-rata morfologi spermatozoa disajikan dalam diagram batang sebagai berikut:

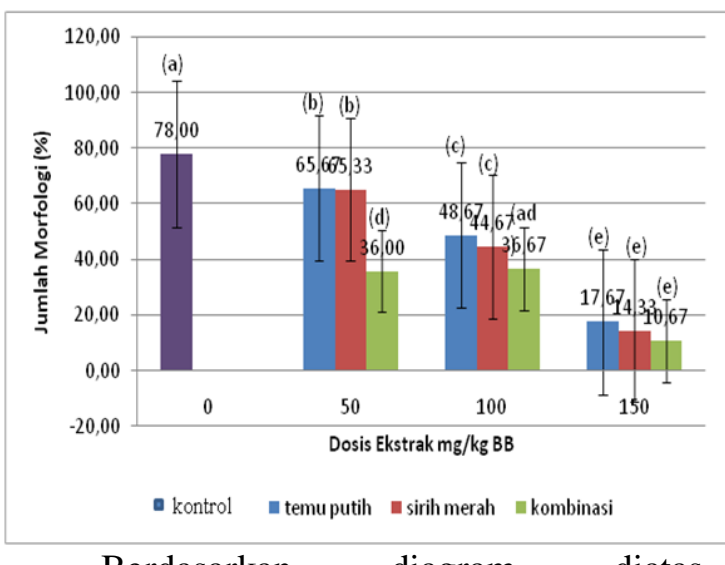

Berdasarkan diagram diatas menunjukkan bahwa rata-rata morfologi pada kelompok perlakuan ekstrak daun sirih merah dan ekstrak temu putih serta kombinasi kedua ekstrak lebih rendah dibanding pada kelompok kontrol.

Dari hasil analisa data menggunakan one way Anova di dapat hasil bahwa ada pengaruh pemberian ekstrak pada berbagai dosis terhadap morfologi spermatozoa mencit $(\mathrm{P}=0,000)$ disajikan dalam lampiran3. Berdasarkan hasil SPSS Uji LSD menunjukkan bahwa morfologi pada perlakuan kontrol berbeda signifikan terhadap semua perlakuan ekstrak. Morfologi pada perlakuan temu putih $50 \mathrm{mg} / \mathrm{kg}$ BB semua ekstrak berbeda signifikan terhdap semua ekstrak kecuali sirih merah $50 \mathrm{mg} / \mathrm{kg}$ BB. Morfologi pada perlakuan temu putih $100 \mathrm{mg} / \mathrm{kg}$ BB berbeda signifikan terhadap semua ekstrak kecuali sirih merah $100 \mathrm{mg} / \mathrm{kg}$ BB. Morfologi pada perlakuan temu putih $150 \mathrm{mg} / \mathrm{kg} \mathrm{BB}$ berbeda signifikan terhadap semua ekstrak keciali sirih merah $150 \mathrm{mg} / \mathrm{kg}$ BB dan kombinasi ekstrak 75:75 mg/kg BB. Morfologi pada perlakuan sirih merah 50 $\mathrm{mg} / \mathrm{kg}$ BB berbeda signifikan terhdap semua perlakuan ekstrak. Morfologi pada perlakuan sirih merah $100 \mathrm{mg} / \mathrm{kg}$ BB berbeda signifikan terhdap semua perlakuan ekstrak. Morfologi pada perlakuan sirih merah $150 \mathrm{mg} / \mathrm{kg} \mathrm{BB}$ berbeda signifikan terhadap semua perlakuan ekstrak kecuali kombinasi ekstrak 75:75 $\mathrm{mg} / \mathrm{kg}$ BB. Morfologi pada perlakuan kombinasi 25:25 $\mathrm{mg} / \mathrm{kg} \quad \mathrm{BB}$ berbeda signifikan terhadap kombinasi ekstrak 75:75 $\mathrm{mg} / \mathrm{kg}$ BB tetapi tidak berbeda signifikan terhadap 50:50 mg/kg BB. Morfologi pada perlakuan kombinasi $50: 50 \mathrm{mg} / \mathrm{kg} \quad$ BB berbeda signifikan terhadap kombinasi 75:75 $\mathrm{mg} / \mathrm{kg} \mathrm{BB}$.

\section{Konsentrasi spermatozoa}

Hasil penelitian dan analisa pengaruh pemberian sirih merah (Piper crocatum) ekstrak temu putih (Curcuma zedoaria Rosc) serta kedua kombinasi ekstrak terhadap penurunan konsentrasi spermatozoa di sajikan dalam lampiran 4. Rata-rata konsentrasi spermatozoa disajikan dalam diagram batang sebagai berikut:

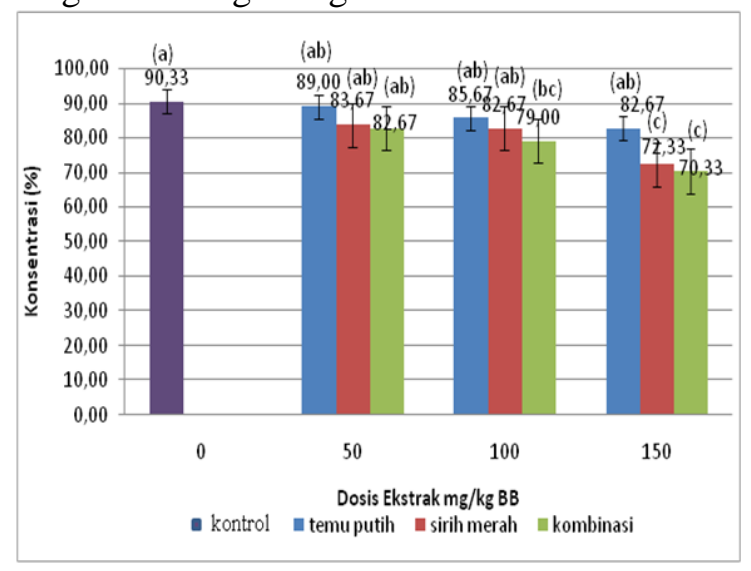

Berdasarkan diagram 5.4 menunjukkan bahwa rata-rata knsentrasi pada kelompok perlakuan ekstrak daun sirih merah dan 
ekstrak temu putih serta kombinasi kedua ekstrak lebih rendah dibanding pada kelompok kontrol.

Dari hasil analisa data menggunakan one way Anova di dapat hasil bahwa ada pengaruh pemberian ekstrak pada berbagai dosis terhadap motilitas spermatozoa mencit $(\mathrm{P}=0,000)$ disajikan dalam lampiran 4 . Berdasarkan hasil SPSS Uji LSD menunjukkan bahwa konsentrasi pada perlakuan kontrol tidak berbeda signifikan terhadap semua ekstrak, kecuali sirih merah $150 \mathrm{mg} / \mathrm{kg} \mathrm{BB}$, kombinasi ekstrak 50:50 $\mathrm{mg} / \mathrm{kg}$ BB dan kombinasi ekstrak 75:75 $\mathrm{mg} / \mathrm{kg}$ BB. Konsentrasi pada perlakuan temu putih $50 \mathrm{mg} / \mathrm{kg}$ BB tidak berbeda signifikan terhadap semua perlakuan ekstrak kecuali sirih merah $150 \mathrm{mg} / \mathrm{kg}$ BB, kombinasi ekstrak 50:50 $\mathrm{mg} / \mathrm{kg}$ BB dan kombinasi ekstrak 75:75 mg/kg BB. Konsentrasi pada perlakuan temu putih $100 \mathrm{mg} / \mathrm{kg}$ BB tidak berbeda signifikan terhadap semua perlakuan, kecuali sirih merah $150 \mathrm{mg} / \mathrm{kg} \mathrm{BB}$ dan kombinasi ekstrak $75: 75 \mathrm{~kg} / \mathrm{mg}$ BB. Konsentrasi pada perlakuan pada perlakuan temu putih $150 \mathrm{mg} / \mathrm{kg}$ BB tidak berbeda signifikan terhadap semua perlakuan ekstrak, kecuali sirih merah $150 \mathrm{mg} / \mathrm{kg}$ BB dan kombiansi ekstrak 75:75 mg/kg BB. Konsentrasi pada perlakuan sirih merah 50 $\mathrm{mg} / \mathrm{kg}$ BB tidak berbeda signifikan terhadap semua perlakuan ekstrak, kecuali sirih merah 150 dan kombinasi 75:75 mg/kg BB.

Konsentrasi pada perlakuan sirih merah $100 \mathrm{mg} / \mathrm{kg}$ BB berbeda signifikan terhadap semua perlakuan ekstrak, kecuali kombinasi ekstrak 25:25 mg/kg BB dan kombinasi ekstrak $\quad 50: 50 \quad \mathrm{mg} / \mathrm{kg} \quad$ BB. Konsentrasi pada perlakuan sirih merah 150 $\mathrm{mg} / \mathrm{kg}$ BB tidak berbeda signifikan terhadap semua ekstrak, kecuali kombinasi 25:25 $\mathrm{mg} / \mathrm{kg}$ BB. Konsentrasi pada perlakuan kombinasi 25:25 $\mathrm{mg} / \mathrm{kg} \quad \mathrm{BB}$ berbeda signifikan terhada kombinasi $75: 75 \mathrm{mg} / \mathrm{kg}$ BB tetapi tidak berbeda signifikan terhadap kombinasi 50:50 mg/kg BB. Konsentrasi pada perlakuan kombinasi ekstrak 50:50 $\mathrm{mg} / \mathrm{kg} \quad \mathrm{BB}$ berbeda signifikan terhadap kombinasi ekstrak 75:75 mg/kg BB.

\subsection{Pembahasan}

Hasil penelitian ini menyatakan bahwa pemberian ekstrak daun sirih merah (Piper crocatum) dan ekstrak temu lawak putih (Curcuma zedoaria Rosc) serta kombinasi ekstrak daun sirih merah (Piper crocatum) dan temu lawak putih (Curcuma zedoaria Rosc) dapat menurunkan motilitas, viabilitas, morfologi dan konsentrasi sperma mencit dengan dosis diatas $50 \mathrm{mg} / \mathrm{kg} \mathrm{BB}$.

Menurut Hafez (2000) yang mengatakan bahwa ekstrak yang diberikan pada berbagai dosis merupakan salah satu faktor terhadap penurunan kualitas spermatozoa mencit (Mus musculus). Ekstrak yang diberikan pada mencit dapat menimbulkan hambatan proses pada tingkat hipotalamus dan menyebabkan gangguan hormonal sehingga mengakibatkan terjadinya gangguan pada sel leydic dalam mensekresi hormon testosteron. Akibat menurunnya kadar testosteron akan mengakibatkan terjadinya gangguan dalam proses glikolisis.

\section{Motilitas Spermatozoa}

Motilitas spermatozoa dibagi menjadi empat kategori yaitu: spermatozoa gerak lurus kedepan, spermatozoa gerak lambat, spermatozoa gerak kedepan dengan kecepatan sedang atau berputar-putar dan spermatozoa tidak bergerak. Terdapat dua faktor yang mempengaruhi motilitas sperma yaitu faktor endogen dan faktor eksogen. Ketersediaan sumber energi merupakan faktor endogen yang sangat penting. Sumber ebergi yang digunkan dalam motilitas sperma adalah Adenosin Tri Phosphat (ATP). (Mudayatiningsih, 2015) hal ini disebabkan adanya senyawa aktif yang terkandung dalam daun sirih merah seperti tannin, flavonoid, saponin, triterpenoid dan alkaloid, begitu juga kandungan senyawa aktif temu putih yaitu tanin, flavonoid dan kurkumin. Ekstrak daun sirih merah dan temu putih dapat menurunkan motilitas spermatozoa mencit dikarenakan adanya kandungan dari kedua ekstrak yang berupa tanin yang dapat menggangu proses transportasi sperma, yaitu menggumpalkan sperma sehingga menurunkan motilitas dan daya hidup 
sperma, akibatnya sperma tidak dapat mencapai sel telur dan pembuahan dapat tercegah (Winarno, 1997).

Pada penelitian Nisa, (2004) yang di suntikan ekstrak temu putih dengan dosis 100 $\mathrm{mg} / \mathrm{kg} \mathrm{bb}, 200 \mathrm{mg} / \mathrm{kg}$ bb, $300 \mathrm{mg} / \mathrm{kg}$ bb pada mencit jantan hasil yang di dapat menyatakan bahwa penurunan motilitas spermatozoa kemungkinan disebabkan oleh senyawa alkaloid yang diduga dapat mengganggu aktifitas enzim ATP-ase pada membran sel spermatozoa dibagian tengah ekor. Enzim ATP-ase tersebut berfungsi mempertahankan homeostasis internal untuk ion natrium dan kalium. Jika aktivitas enzim ATP-ase terganggu, maka homeostasis ion natrium dan kalium akan terganggu sehingga konsentrasi $\mathrm{Na}+$ intrasel meningkat, gradien $\mathrm{Na}+$ melintasi membran sel akan menurun sehingga pengeluaran $\mathrm{Ca} 2+$ juga akan mengalami penurunan (Ganong, 2001). Apabila ion $\mathrm{Ca} 2+$ berkurang maka membran akan kehilangan kemampuannya untuk mengangkut bahan-bahan terlarut ke dalam sitoplasma (Haryati, 2003). Dengan terganggunya permeabilitas membran sperma akan menyebabkan terganggunya transpor nutrien yang diperlukan oleh spermatozoa untuk pergerakannya.

\section{Viabilitas Spermatozoa}

Pengamatan viabilitas spermatozoa dilakukan dengan cara menghitung rata-rata spermatozoa hidup dan mati dari setiap 100 spermatozoa pada semua kelompok.

Dari grafik 5.2 menunjukkan bahwa terdapat kecenderungan yang berbeda signifikan terhadap perlakuan lainnya. Viabilitas spermatozoa adalah daya hidup spermatozoa dalam pengamatan viabilitas spermatozoa sperma yang hidup tidak harus bergerak tetapi memiliki kepala warna bening/putih sedangkan yang mati berwarna merah. Tujuan pemberian ekstrak daun sirih merah yaitu menurunkan viabilitas spermatozoa mencit dengan kandungan yang ada pada daun sirih merah seperti flavonoid, saponin dan alkoloid, senyawa aktif yang di duga dapat menyebabkan tingginya konsentrasi testosteron akan berefek umpan balik negatif ke hipofisis yaitu tidak melepaskan FSH atau LH, sehingga akan menghambat spermatogenesis (Sutiarso, 1994).

Menurut toelihere (1993), kadar asam laktat yang cukup tinggi akan menghambat aktifitas metabolisme sel dan juga merupakan racun bagi spermatozoa yang dapat menyebabkan kematian sel spermatozoa.

\section{Morfologi Spermatozoa}

Morfologi spermatozoa pada penelitian ini di temukan abnormalitas spermatozoa pada pemberian ekstrak sirih merah, namun yang optimal dalam mengurangi spermatozoa normal adalah ekstrak kombinasi dengan berbagai dosis. Hal ini disebabkan kandungan senyawa dari daun sirih merah yaitu senyawa tannin dan diastase yang terkandung dalam ekstrak daun sirih. Senyawa ini dapat mempengaruhi produksi hormon GnRH yang menghambat hipofisis anterior mengahsilkan FSH dan LH, sehingga respon terhadap testis juga akan terjadi penurunan yang akan memengaruhi sel sertoli dan sel leydig untuk menghasilkan hormon testosteron yang memengaruhi proses spermatogenesis, sehingga kualitas sperma juga akan terganggu, sedangakan flavonoid yang terdapat dalam temu putih merupakan suatu senyawa yang bersifat estrogenik, karena mampu merangsang pembentukan estrogen dalam tubuh yang akan meningkatkan kadar estrogen. Peningkatan kadar estrogen akan memberikan umpan balik negatif ke hipofisis anterior, yaitu tidak melepaskan FSH dan LH. Penurunan kadar LH menyebabkan gangguan terhadap sekresi testosteron oleh sel Leydig. Sumapta (2005).

\section{Konsentrasi Spermatozoa}

Konsentrasi sperma merupakan densitas (jumlah) sperma tiap $\mathrm{ml}$ semen. Konsentrasi sperma memang merupakan salah satu faktor penting untuk mendukung keberhasilan pembuahan (Anna, 2010). Konsentrasi atau jumlah spermatozoa/ml semen, dihitung dengan alat hemacytometer Neubauer. Jumlah spermatozoa dihitung 
dengan melihatnya dibawah mikroskop perbesaran 400 kali. Dari hasil yang telah dilakukan terlihat bahwa ekstrak sirih merah $150 \mathrm{mg} / \mathrm{KgBB}$ tidak berbeda signifikan terhadap kombinasi dosis 25: $25 \mathrm{mg} / \mathrm{KgBB}$ dan $75: 75 \mathrm{mg} / \mathrm{KgBB}$, hal tersebut terlihat dari grafik 5.3 yang mengalami penurunan sehingga dapat digunakan sebagai alat antifertilitas pria. Jumlah spermatozoa yang menurun disebabkan adanya senyawa aktif yang terdapat pada temu putih dan sirih merah yaitu, alkaloid, tanin, saponin, flavonoid, triterpenoid.

Adanya penggunaan kombinasi temu putih dan sirih merah menimbulkan potensi yang baik dalam penurunan spermatozoa, karena adanya senyawa aktif yang lebih kuat ketika bereaksi.

\section{KESIMPULAN}

Berdasarkan hasil yang telah dilakukan dalam penelitian ini, maka dapat disimpulkan:

1. Pemberian ekstrak temu putih (Curcuma zedoaria Rosc) dan ekstrak Daun Sirih Merah (Piper crocatum) serta kombinasi kedua ekstrak berpotensi terhadap penurunan motilitas sperma mencit (Mus musculus L.), dimana yang dapat menurunkan adalah yang berdosis diatas $50 \mathrm{mg} / \mathrm{kg} \mathrm{BB}$.

2. Pemberian ekstrak temu putih (Curcuma zedoaria Rosc) dan ekstrak Daun Sirih Merah (Piper crocatum) serta kombinasi kedua ekstrak berpotensi terhadap penurunan viabilitas sperma mencit (Mus musculus L.), dimana yang dapat menurunkan adalah yang berdosis diatas $50 \mathrm{mg} / \mathrm{kg} \mathrm{BB}$.

3. Pemberian ekstrak temu putih (Curcuma zedoaria Rosc) dan ekstrak daun sirih merah (Piper crocatum) serta kombinasi kedua ekstrak berpotensi terhadap penurunan morfologi sperma mencit (Mus musculus L.), dimana yang dapat menurunkan adalah yang berdosis diatas $50 \mathrm{mg} / \mathrm{kg} \mathrm{BB}$.

4. Pemberian ekstrak temu putih (Curcuma zedoaria Rosc) dan ekstrak daun sirih merah (Piper crocatum) serta kombinasi kedua ekstrak berpotensi terhadap penurunan konsentrasi sperma mencit (Mus musculus L.), dimana yang dapat menurunkan adalah yang berdosis diatas $50 \mathrm{mg} / \mathrm{kg} \mathrm{BB}$.

\section{REFERENSI}

Arisandi, A. 2007. Efektivitas Esktrak Steroid Teripang Untuk Memanipulasi Kelamin Udang Galah. http://repository.ipb.ac.id/handle/123456 789/41399

Akbar B. 2010. Tumbuhan Dengan Kandungan Senyawa Aktif Yang Berpotensi Sebagai Bahan Antifertilitas. Jakarta : Adabia Press pp 6-7

Ashok, P., B. Meenakshi. 2004. Contraceptive Effect Of Curcumalonga (L.) in Male Albino Rat. Available at: http://www.asiajandrol.com Opened : 5.10.2007

Biro Pusat Statistik. 2011. Badan koordinasi keluarga berencana nasional. Depkes.Macro International. Survey Demografi dan Kesehatan Indonesia.

Ermayanti, N.G.A.M., A.A.S.A. Sukmaningsih, D. Ariani. 2005. Pengaruh Infus Kayu Amargo (Quassia amara Linn) Terhadap Testosteron Mencit (Mus musculus L.) dan Reversibilitasnya. Jurnal Biologi IX ( 2 ) : 62-64.

Fitria, L. 2000. Pengaruh Ekstrak Kuda Laut (Hippocampus kuda Blecker) terhadap Spermatogenesis dan Kualitas Spermatozoa Mencit Jantan (Mus musculus). [Skripsi]. Yogyakarta: Fakultas Biologi UGM

Handajani, N.S. 2003. Aktivitas Sitostatika Temu Putih (Curcumazedoaria (Berg.) Roscoe.) pada Sel-sel Spermatogenik Mencit (Mus musculus L.). Jurnal BioSMART 5 (2) : 120-123.

Harborne, J.B. 1987. Metode Fitokimia Penuntun Cara Modern Menganalisis Tumbuhan. Penerbit ITB. Bandung. 
Haryati. 2003. Biomembran Available at: http://www.USUdigitallibrary.com Opened: 02.11.2007

Herrera CL, Ramos EV, Villanueva BA.1984. Philppine Plants as Possible Sources of An t i f e r t i l i t y Agent. Philipine J. Sci ; 91-129.

Manoi, F., 2007, Sirih Merah sebagai Tanaman Multifungsi, Warta Puslitbangbun Vol.13 (2).

Mishra, R.K. and Singh, S.K. Reversible antifertility effect of aqueous rhizome extract of Curcuma longa L. in male laboratory mice. Contraception 2009;79 (6):479-487

Moeloek.N. 2002. Perkembangan Kontrasepsi Laki-Laki. Pertemuan Ilmiah Tahunan XIV Perkumpulan Andrologi Indonesia. Denpasar.

Mudayatiningsih, S., Dewi, E. S., Suryandari, H., dan Isnaeni. 2015. Ekstrak Daun Sirih (Piper betle L) Dan Kualitas Spermatozoa Pada Mencit (Mus musculus). Jurnal Informasi Kesehatan Indonesia (JIKI). 1 (2) : 127-136.

Murwati, R., E. Meiyanto. 2004. Efek Ekstrak Rimpang Temu Putih Terhadap Pertumbuhan Tumor Paru Fase Post Inisiasi pada Mencit Betina di Induksi Benzo(a)piren. Majalah Farmasi Indonesia 15 (1) : 7-12.

Kimball, J.W. 1996. Biologi. Erlangga, Jakarta.

Nisa, L.S. 2004. Kontrasepsi Alami untuk Pria. Erlangga, Jakarta.

Partodihardjo, S. 1980. Ilmu Reproduksi Hewan. Jakarta: Penerbit Mutiara

Purwaningsih, E. 2003. Pengaruh Ekstrak Daun Kemuning (Murraya paniculata, L) terhadap Kualitas Sperma Manusia In Vitro. Jurnal Kedokteran Yarsi 11 (2): 77-84.
Rahmat Rukmana.1995. Temulawak: Tanaman Rempah dan Obat. Jakarta: Kanisius. Halaman: 15.

Ratnasooriya, W. D., dan Premakumara. G.a.s. 1997. Piper betle Leaves Reversibly Inhibits Fertility of Male Rats. Vidyodaya Journal of Science. Vol $7: 15-21$.

Robaire, B., L. Hermo. 1988. Efferent Ducts, Epididymis, and Vas Deferens : Structure, Functions and Their Regulation. In : The physiology of reproduction. Eds. E. Kuobil and J. Neil. Raven Press, Ltd. New york. p. 10581059.

Rugh, R. 1968. The Mouse: Its Reproduction and Development. Burger Publishing Company. New York. hlm. 20.

Sherwood, L. 2007. Human physiology from cells to systems 6th Edition. California: Thomson Higher Education

Suartha, I.N. 2005. Ekstrak Daun Jung Rahab (Baeckea frutescens Linn.) Menghambat Spermatogenesis Mencit (Musmusculus). Program Pascasarjana. Program Studi IlmuKedokteran Reproduksi. Universitas Udayana. Tesis S-2.

Sudewo, B., 2007, Basmi Penyakit dengan Sirih Merah, PT Agromedia Pustaka, Jakarta.

Sumaryanti A. 2004. Tahun ini KB Laki-Laki Mulai Digalakkan. Badan Koordinasi Keluarga Berencana Nasional. http:www//.bkkbn.go.id/ article_detail.php diaskses 26 oktober 2010.

Susetyarini, R, E. 2009. Efek aktif daun belintasterhadap kadar testosteron tikus putih (Ratus norwegicus) jantan.

Yatim dan wildan. 1994. Reproduksi dan Embryologi. Penerbit Tarsito: Bandung 